Ivanka Kuić: Javno znanje o tuberkulozi i djelovanje Društva za suzbijanje tuberkuloze u Splitu (1918-1941)

\title{
Javno znanje o tuberkulozi i djelovanje Društva za suzbijanje tuberkuloze u Splitu (1918-1941)
}

\author{
Ivanka Kuić \\ Sveučilišna knjižnica u Splitu \\ e-mail:kuicivanka@gmail.com
}

SAŽETAK: Tuberkuloza je bila velik zdravstveni problem u Splitu između dvaju svjetskih ratova (1918-1941). U zdravstvenom prosvjećivanju, kao jednoj od preventivnih metoda liječenja te opake bolesti na tragu Štamparovih socijalno-medicinskih ideja, razbijanju predrasuda i senzibiliziranju javnosti za suočavanje s posljedicama bolesti, važnu su ulogu imale znanstvene publikacije, časopisi i lokalne novine. U radu se uspostavlja kontinuitet stvaranja zabilježenoga javnoga znanja, s posebnim osvrtom na ulogu masovnih medija: Novoga doba, važnoga političko-informativnoga dnevnika koji je izlazio od 1918. do 22. travnja 1941., i fadranskoga dnevnika, koji je izlazio između 1934. i 1938. Oba su dnevnika uspješno obavljala društvenu funkciju informiranja, oblikovanja javnoga mišljenja i širenja znanja, prenoseći svu složenost i nužnost modernizacijskih praksi koje su mijenjale Split i činile ga modernim gradom. Jedna od tih modernizacijskih praksi bila je i borba s tuberkulozom kao ozbilinim socijalno- medicinskim problemom.

Ključne riječi: Andrija Štampar; tuberkuloza; socijalno-medicinske metode; Split 1918-1940., Novo doba, Jadranski dnevnik

\section{Osnovne postavke Štamparove socijalne medicine}

I nakon šezdeset godina od smrti, Andrija Štampar ostaje i dalje velika i pomalo zatajena inspiracija hrvatske medicine i medicinske znanosti. Njegova misao i dalje je predmet bavljenja povjesničara medicine, kulturnih povjesničara, sociologa, liječnika koji praktično ostvaruju zadatke liječenja ljudi, kao i hrvatskoga društva u cjelini. Njegovu se socijalnu misao danas, nakon društvenih, političkih i socijalnih promjena kroz koje je prošlo naše društvo, sve više »konfrontira« s rastućim trendom komodifikacije naših tijela prema neoliberalnim tržišnim praksama. ${ }^{1} \mathrm{U}$ suvremenom svi-

1 »Danas, više nego ikad, stanje bolesti ili zdravlja, naše dijagnoze, usko su vezane uz troškove, no ne realne nego one koji su određeni globalnim tržišnim nadmetanjima i ritmom „života“ slobodnoga 
jetu globalizma i neoliberalnoga kapitalizma, u kojem su bolest i zdravlje na udaru globalnih korporacija (primjerice farmaceutskih), ideologija koju je Štampar zastupao i danas ostaje točka atrakcije hrvatske zdravstvene politike i mjesto prijepora različitih pristupa organizaciji suvremene hrvatske medicinske prakse jer zastupa interes čovjeka - ma tko on bio - u društvu u kojem živi. Središte je njegove ideologije, koju je oblikovao u jednom članku već 1911., ${ }^{2}$ čovjek, njegovo zdravlje i fizička snaga kao gospodarska vrijednost te socijalno-ekonomski uvjeti kao uvjeti čovjekova života. Na krilima naprednjačke ideologije, koja u kontekstu tadašnjih prilika reflektira društvenu potrebu za kulturnom i ekonomskom preobrazbom hrvatskoga društva, za napretkom i subjektivitetom svakoga pojedinca, ${ }^{3}$ Štampar je posebno posvećen narodnom zdravlju i siromašnijim slojevima čiji život, socijalne i kulturne prilike dobro poznaje. Načelo humanosti i humanizam, stavljanje čovjeka u središte društvena interesa temeljna su načela njegove profesionalne etike. Kako piše Grmek, »Štampar je bio liječnik praktičar, ali ne na individualnoj razini; njegovi pacijenti bili su ljudske zajednice $\ll^{4}$ Stoga ovom radu pristupamo istraživački, a u fokus istraživanja stavljamo upravo sposobnost i integrativnu snagu Splita kao »ljudske zajednice«, kao urbanističko-socijalne cjeline koja u istraživanom razdoblju postupno dobiva konture modernoga grada i angažira se u saniranju takvih društvenih problema kakva je bolest tuberkuloze. Kao jednu od važnih točaka socijalne medicine, koju definira kao »socijalizovana znanstvena i praktična medicina «, ${ }^{5}$ tj. socijalne terapije, on ističe socijalnu pedagogiju i popularizaciju te korištenje različitih tiskanih sredstava u širenju znanja o bolesti, higijenskom i racionalnom životu kao načinu suzbijanja socijalnih endemskih bolesti. ${ }^{6}$

tržišta«. Sanja Špoljar-Vržina: Neoliberalno „zdravlje“, globalna bolest i Štamparova medicina, Društvena istraživanja, 17(2008) 6, str. 1000.

2 Andrija Štampar: Socijalna medicina. U: Mirko Dražen Grmek (prir.), U borbi za narodno zdravlje: izabrani članci Andrije Štampara, Zagreb 1966, str. 51-54.

3 Isto, str. 52. »Ako je ideal oslobađanje čovjeka u svakom pogledu duševnoga i tjelesnog života prvi u idealima modernim, onda bi ideal zdravlja i fizičke snage morao biti odmah na drugom mjestu.«

4 Mirko Dražen Grmek: Životni put Andrije Štampara, borca za unapređenje narodnog zdravlja. U: U borbi za narodno zdravlje: izabrani članci Andrije Štampara, str. 14.

5 U pristupnom predavanju održanom na Medicinskom fakultetu u Zagrebu 1923. prigodom izbora za profesora higijene i socijalne medicine Štampar je rekao: „Socijalna medicina je nauka koja se bavi ispitivanjem međusobnog utjecaja socijalnih odnosa i patoloških pojava u narodu i pronalaženjem mera socijalnog karaktera za unapređenje narodnog zdravlja.« U: $U$ borbi za narodno zdravlje: izabrani članci Andrije Štampara, str. 85.

6 »Popularizacija medicine je moćan faktor pri njezinu djelovanju. Općem širenju pučke prosvjete treba da pristupi i širenje pouka medicinskih. Izdavanjem poučnih, pučki dobro pisanih knjižica zdravstvenog sadržaja, priređivanjem isto takvih predavanja, osnivanjem društava s tom svrhom, učinit će se mnogo uspješnog i lijepog na području socijalne medicine.« A. Štampar: Socijalna medicina. U: $U$ borbi za narodno zdravlje: izabrani članci Andrije Štampara, str. 54. 
Povjerenje u znanje kao uvjet napretka i sretnijega života ideologija je koju Štampar slijedi od studentskih dana. U članku »Naša ideologija « naglasio je znanje kao najvažniji čimbenik borbe protiv bolesti. ${ }^{8}$ Ovo je doba socijalizacije i demokratizacije medicine, naglašava $u$ istom članku, kao rezultat velikih socijalnih pokreta i napora reformatora, među koje ubraja i liječnike koji su se bavili narodnim zdravljem. Označivši zdravlje kao pozitivnu kulturnu činjenicu, demokratizacija znanja postala je uvjet borbe za zdravlje.

Ideju brige za narodno zdravlje Štampar je zastupao već početkom XX. stoljeća kao student medicine u Beču u člancima koje je objavljivao u nekim časopisima. ${ }^{9}$ U pokušaju da uspostavimo kontinuitet prisutnosti njegova ideala u Splitu i Dalmaciji i utjecaja koji je morao imati, treba svakako poći od serije članaka objavljenih 1909. u časopisu Zvono. U jednom od njih izvještava o modernim metodama borbe protiv sušice u Njemačkoj, a u drugom ${ }^{10}$ je posvećen ulozi liječnika kao socijalnoga radnika i prosvjetitelja. Biti liječnik na selu, smatra Štampar, zahtjevna je profesija, zahtijeva veliko znanje, veće nego znanje liječnika u gradu i humanost, a liječnik i učitelj mogu puno učiniti na području pučke prosvjete. Nije dovoljno biti dobar liječnik nego treba biti i dobar čovjek. Literatura i pisana riječ za Štampara su uvijek bili važan oslonac u radu, jedan od socijalnih uvjeta znanja. Na žalost, piše on, u Hrvatskoj nema popularne medicinske literature kao u drugim zemljama. Njegove su ideje već tada bile poznate javnosti Splita. ${ }^{11}$ Malu knjižicu Pouke o zdravlju objavio je 1910. i posvetio je u cijelosti borbi protiv tuberkuloze. Ta je knjižica također dospjela do splitske stručne i druge javnosti i mogla se nabaviti u knjižari Vinka Jurića u Splitu. U njoj je Štampar pokazao poznavanje i razumijevanje etiologije i prirode tuberkuloze u Hrvatskoj, posebno u hrvatskom selu. U svojoj knjižici iznosi niz pouka o zdravom životu i ideju o zdravlju kao najvećem bogatstvu koje treba čuvati, što čini srž njegove medicinske misli. Misao o znanju iznio je u nekoliko proročanskih rečenica: »Znanje je moć. Tko više zna više može. U neznanju svašta se može dogoditi. Znanjem se i bolest suzbija. Ali nije dovoljno znati, treba i htjeti. Bolest će se tek

7 Andrija Štampar: Naša ideologija. U: U borbi za narodno zdravlje: izabrani članci Andrije Štampara, str. 99-101.

8 »Suzbijanje neznanja, širenje pismenosti i opšteg znanja, od većeg je značaja za unapređenje narodnog zdravlja od mnogih čisto zdravstvenih ustanova.«Ibid., str. 100.

9 U jednom članku Štampar socijalnu medicinu definira kao nauku »koja se bavi ispitivanjem međusobnog utjecaja socijalnih odnosa i patoloških pojava u narodu i pronalaženjem mera socijalnog karaktera za unapređenje narodnog zdravlja«. (»O socijalnoj medicini«. U: U borbi za narodno zdravlje: izabrani članci Andrije Štampara, str. 85).

10 Misli se na članak »Borba protiv sušice«. Zvono, 1909., br. 14, str. 371-374; drugi spomenuti članak je »Iz područja socijalne medicine: liječnik na selu«, Zvono, 1909., br. 16, str. 437-440.

11 Primjerak časopisa Zvono koji se čuva u Sveučilišnoj knjižnici, prema ex librisu, potječe iz privatne knjižnice dr. Ante I. Štambuka. 
tada moći suzbiti, ako se dobro upozna...«.12 Štampar smatra da se to može postići širenjem znanja o bolesti jer »kako će onaj ići u bolnicu koji ne zna ništa o zdravlju i bolesti, nego čeka da samo od sebe prođe «. ${ }^{13}$ Od tada je širenje znanja o bolesti i načinima na koji se ona suzbija jedna od temeljnih postavki Štamparove socijalne medicine koju su prihvatili i ugledni splitski liječnici u etatiziranim zdravstvenim ustanovama. Osvrćemo se na ovu knjigu i zato što u njoj iznosi i ideju o potrebi osnivanja društava za očuvanje narodnoga zdravlja po ugledu na druge narode, pokretanja »pučkih zdravstvenih novina«, zdravstvenoga prosvjećivanja, nasuprot tezi da »neukom svijetu nije dobro tumačiti bolesti, jer da se tim više škodi nego koristi«. Štampar smatra da se liječnici trebaju uključiti u zdravstveno prosvjećivanje i pisanjem popularnih knjižica i članaka: »trebalo bi nam i ljudi, koji bi pravo pučki znali pisati, da svatko može ono razumjeti, što napišu«. U uvodu također napominje: »Nije naime dosta, da se knjiga napiše i izda nego treba da se čita «. ${ }^{14}$ Ta je jednostavno pisana knjižica puna poslovičnih izreka o zdravlju, šireći Štamparevu misao i moderna znanja i dostignuća medicine u liječenju tuberkuloze, držimo, bila diskurzivni preokret, uzor i motiv splitskim liječnicima u borbi protiv tuberkuloze te otuda ima mjesta u povijesti medicinske knjige u Splitu. Ona zasigurno ulazi u katalog temeljnih publikacija koje su Split uvele u kampanju borbe protiv tuberkuloze.

Andrija Štampar nije samo reformator sustava zdravstvene zaštite u smislu metodologije i organizacije rada nego i ideolog koji je odredio etiku, vrijednosti, orijentire i prioritete stručnoga rada. Kao reformator, on se u svojoj strategiji oslonio na pisanu riječ ${ }^{15}$ i širenje informacija i znanja o zaraznim bolestima pisanim sredstvima, dajući liječnicima konkretne zadatke prosvjećivanja i stvaranja korpusa javnoga znanja na korist društva i pojedinca. Jezgra toga znanja, sudeći prema njegovim člancima, trebaju biti istinite i objektivne informacije zasnovane na znanstvenim i praktičnim socijalno-medicinskim spoznajama i kontekstualizirane zbiljom jer su bez toga ciljevi koje je postavio bili teško ostvarivi. Općenito se »javno znanje« definira kao zabilježeno znanje koje je dostupno svima, koje se stvara u nekom društvenom prostoru kao rezultat međusobne komunikacije i interakcije pripadnika nekoga društva

12 Andrija Štampar: Pouke o zdravlju, Zagreb 1910., str. 6.
13 Isto, str. 30.
14 Pouke o zdravlju, str. 29-31.
15 Željko Dugac: Kako biti čist $i$ zdrav: zdravstveno prosvjećivanje u međuratnoj Hrvatskoj, Zagreb 2010. Autor se u svojoj knjizi bavi iscrpno metodama zdravstvenoga prosvjećivanja u međuratnom periodu. Također ističe da se zalaganje za uporabu pisanih materijala uočava odmah nakon Prvoga svjetskoga rata, za što se zalagalo Povjerenstvo za suzbijanje tuberkuloze već 1919. u Zagrebu. »Provoditelji zdravstveno-prosvjetnih akcija tiskane su materijale smatrali podesnim medijem za širenje svojih ideja, ali je za njihovu upotrebu bilo potrebno ispuniti nekoliko važnih elemenata.« To je u prvom redu bila pismenost, ali i dostupnost (str. 68). 
ili organiziranoga djelovanja, većinom uz pomoć medija. ${ }^{16}$ Javno je znanje ono znanje »kojem želimo podučiti našu djecu, to je ono što utjelovljuje kanon i prenosi se na sljedeće generacije «. ${ }^{17}$ Prema tome, to je eksplicitna reprezentacija društvenoga znanja u jeziku ili nekoj drugoj formi. Drugo je pitanje društvenih dimenzija znanja, tj. socijalnih uvjeta znanja. ${ }^{18}$ Možemo se stoga, nakon upoznavanja s medicinsko-teorijskim postavkama Andrije Štampara, zapitati u kakvim je relacijama bilo znanje liječnika prema znanju naroda o zaraznim bolestima i tuberkulozi, te jesu li liječnici sami mogli i uz kakve napore prosvjećivati nepismen i socijalno i ekonomski zapušten narod, bez šire društvene akcije. Odgovor na to pitanje zahtijeva i poznavanje nekih ključnih društvenih i socijalnih činjenica o Splitu koje bi omogućile bolje razumijevanje odnosa tadašnjih masovnih medija i stvarnosti te napora splitskih liječnika koji su djelovali u smjeru Štamparovih uputa o sprječavanju bolesti.

Općenito se u međuratnom razdoblju Split nalazio u tranziciji prema otvorenom i modernom gradu. U promijenjenim društvenim uvjetima nove države, njegovi su razvojni potencijali dolazili do izražaja više zahvaljujući sposobnostima pojedinaca s »tehničkim i funkcionalnim kompetencijama«, dakle »odozdo«, nego pomoći središta koje je s vremenom sve manje podržavalo splitske projekte. Položaj najvećega grada na Jadranu, na koji je s pravom računao, mijenja se teritorijalnim podjelama u Kraljevini SHS/Jugoslaviji, koje umanjuju njegovo značenje u širem okruženju. Na-

16 Miroslav Tuđman smatra da su tradicionalni stavovi informacijskih znanosti da je javno znanje svijet objektivnih i istinitih informacija. To su stavovi koji vrijede za sredinu XX. stoljeća, ali danas dolazi do dekonstrukcije toga svijeta pod utjecajem informacijske znanosti koja digitalnu informaciju stavlja u središte znanja koja više ne funkcionira kao javno znanje i nema zadaću prenositi istinite i objektivne informacije. Vrijeme u kojem se nalazimo, način proizvodnje tekstova i objavljene informacije kontekstualizirane zbiljom upućuje na činjenicu da je javno znanje još uvijek bilo objektivna i istinita društvena forma. Vidi: Miroslav Tuđman: fe li informacijska znanost još uvijek društvena znanost? http://infoz.ffzg.hr/infuture/2007/pdf/1-04\%20Tudjman,\%20Miroslav,\%20Je\%201i\%20informacijska\%20znanost\%20jos\%20uvijek\%20drustvena\%20znanost.pdf (pristupljeno 2. I. 2019)

$17 \gg$ Za formiranje javnog znanja presudna je instrumentalizacija svih funkcija, a posebno informacijske funkcije. No i ova je forma znanja kulturno i filozofski uvjetovana jer polazi od pretpostavke o: postojanju objektivnog znanja; autonomnoj egzistenciji objektivnog znanja neovisnoj od spoznajnog subjekta; podjeli rada i diferencijaciji socijalnih uloga na čemu se i zasniva rast informacijske infrastrukture; egzistenciji javnog znanja kao autonomnog predmeta kojim se bave te službe, pa se govori o informacijskom tržištu, informacijskoj ekonomiji, informacijskim proizvodima i uslugama itd.« Miroslav Tuđman: Epistemološki postav informacijske znanosti, str. 108. https://www.researchgate.net/publication/281099573_Epistemologijski_postav_informacijske_znanosti_Epistemology_of_the_information_ science (pristupljeno 3. I. 2019). Vidi i: Stephen Downes: Connectivism and Connective Knowledge, str. 315-316. https://www.downes.ca/files/books/Connective_Knowledge-19May2012.pdf (pristupljeno 3. I. 2019)

18 Socijalni epistemolog Frederich Schmitt podrazumijeva »utjecaj društvenih odnosa, interesa, uloga i institucija... Oduvijek se priznaje da socijalni uvjeti podupiru znanje tako što čine materijalno mogućima opažanje, sjećanje i razmišljanje...«. John Greco i Ernest Sosa (prir.). Epistemologija: vodič u teoriji znanja, Zagreb 2004. 
kon početnoga optimizma, odnos prema središnjoj vlasti radikaliziran je nemogućnošću autonomnoga djelovanja u rješavanju brojnih socijalnih i gospodarskih problema i izostanku pomoći središnje vlade i planova (cementna industrija, industrija konzerviranja ribe, i dr.) i ostvarenju municipalnih prava i identiteta. $U$ okvir tih problema ulaze i zdravstveni problemi o kojima ovdje pišemo. Koristeći se jezičnim aparatom Ivana Rogića kada piše o hrvatskim modernizacijama, sažeto možemo reći da je Split, zajedno s velikim zaleđem, živio u uvjetima »zapriječenostik, »usporenosti«i $i$ nedovršenosti«: industrijalizacije, urbanizacije, samovoljne birokratizacije središnjih vlasti. Kao grad bez velikih industrijskih poduzeća, Split nije mogao osigurati prihvat doseljenih iz okolnih pasivnih mjesta koji sa sobom donose niz problema pa i bolesti, niti im ponuditi radno mjesto i bolje uvjete života. ${ }^{19}$ Asanacija grada, uređenje gradske infrastrukture te osnivanje potrebnih zdravstvenih ustanova i na kraju početak gradnje bolnice 1931. godine koja nije dovršena do 1941., postupno i u skladu s ekonomskim mogućnostima, omogućavali su rješavanje problema skučenih i nezdravih splitskih područja, izvora svekolike zaraze i boleštine. U takvoj situaciji lokalne su novine, posebno Novo doba i fadranski dnevnik kao novine s dužim kontinuitetom izlaženja, uvodeći novu društvenu praksu informiranja o zaraznim bolestima, upozorili javnost na razmjere problema sustavno pritišćući društvo i središte vlasti, razvijajući suosjećanje pojedinaca prema oboljelima i siromašnima te postupno stvarajući uvjete za organizaciju korpusa javnoga znanja o problemu zaraznih bolesti. To je znanje zasigurno imalo učinak na ponašanje stanovništva i na javno djelovanje.

Stoga su deskripcija medijske pojavnosti (znanstvene publikacije, časopisi i novine) procesa zdravstvenoga prosvjećivanja, u Splitu, u sučeljavanju s tuberkulozom i drugim zaraznim bolestima, diskurzivna praksa kao proizvodnja tekstova, način razmišljanja, odnosa i ponašanja te artikulacija toga problema kao stvarne društvene i socijalne opasnosti po pojedinca i po društvo, srž ovoga istraživanja.

\section{Tuberkuloza u Splitu i znanstvene publikacije}

Ulaskom u novu zajednicu, Kraljevinu SHS, Split nastavlja fazu produžene prve modernizacije - urbane transformacije i postupne promjene svih vidova javnoga života. Kao najveće urbano naselje, nakon gubitka Zadra i Rijeke ugovorom u Rapallu

19 Ivan Rogić, Ivan Čizmić: Modernizacija u Hrvatskoj i hrvatska odselidba, Zagreb 2011., str. 45-53. Prema autorima, nakon 1918. oblikuje se jedna nadnacionalna strategija razvoja i nova dvostruka perifernost kao osnovni problemi, što znači manjak državne potpore lokalnoj politici i projektima, što dovodi do stratifikacije »poduzetničke moći« po nacionalnoj liniji, dok mala poduzeća koja ne mogu ponuditi višak radnih mjesta i manjak osnovnoga obrazovanja većine stanovništva dovode do golemih socijalnih razlika i produbljuje distancu grad - selo, ali u Splitu i grad-periferija, uza sva nastojanja uprave da se oblikuje moderan grad koji urbanizacijski povezuje svoje dijelove. 
1920., Split postaje političko, gospodarsko i kulturno središte Dalmacije. Split se i demografski mijenja: iz zaleđa dolazi velik broj radnika u potrazi za poslom i boljim uvjetima života, pa se njegovo stanovništvo povećava s 25 045, koliko je imao prema popisu iz 1921., na 35417 stanovnika prema popisu iz 1931. godine, do 46001 stanovnika $1941 .{ }^{20}$ Usvajanjem Regulacijskoga plana otvorene su mogućnosti za urbanističku preobrazbu - gradnju stanova, zdravstvenih ustanova, javnih, znanstvenih i obrazovnih ustanova i oblikovanje novoga lica grada. Međutim, mnoštvo problema, ekonomsko i kulturno stanje stanovništva, posebice radnika i težaka, kao posljedice Prvoga svjetskoga rata, gladi, društvenih i socijalnih problema, kulturne zapuštenosti, velike nepismenosti, ${ }^{21}$ raširenosti zaraznih bolesti, otežavali su brzo i učinkovito rješavanje gradskih problema. Javno zdravstvo u toj situaciji moralo je što hitnije djelovati. Zahvaljujući naporima Andrije Štampara i suradnji sa Zdravstvenim odjelom za Dalmaciju, prvi upravitelj kojega je bio liječnik Šime Ljubić, u Splitu su već 1922. osnovani Bakteriološka stanica, zaslugom liječnika Josipa Škarića, ${ }^{22}$ Institut za proučavanje i suzbijanje malarije u Trogiru, koji je vodio liječnik Andrija Sfarčić, Ambulanta za venerične i kožne bolesti koju je vodio Ivo Stalio, postavljeni su temelji istraživačke, dijagnostičke i preventivno-profilaktičke prakse u Splitu. Godine 1923. osnovan je i Dispanzer za grudne bolesti. Sve su te ustanove pružale besplatnu liječničku pomoć. ${ }^{23}$ Njihovim spajanjem nastao je 1929. Higijenski zavod (danas Nastavni zavod za javno zdravstvo Splitsko-dalmatinske županije), a njegov direktor također je bio Josip Škarić. Teritorijalnim podjelama koje su u tom razdoblju provedene, Split je bio sjedište Splitske oblasti (1922-29), Primorske banovine (1929-39), a od 1939. u sastavu je Banovine Hrvatske.

Ekonomska se situacija 1930-ih godina pogoršavala pod utjecajem svjetske ekonomske krize. Zbog velikoga doseljavanja okolnoga stanovništva posebno je akutno bilo pitanje izgradnje novih stanova za radnike, poboljšanje uvjeta stanovanja i saniranje zaraznih bolesti u središtu grada oko Dioklecijanove palače, opskrba pit-

20 Zdravka Jelaska Marijan: Grad i ljudi: Split 1918.-1941. Zagreb 2009., str. 25-29.

21 Ibid., str. 298-299. Prema podatcima Anagrafskoga zavoda, u Splitu je posljednjega dana 1923. od 28684 stanovnika bilo 26,96\% nepismenih, a posljednjega dana 1924. od 29655 stanovnika 28,44\% nepismenih. Primjetno je kolebanje u broju stanovnika.

22 O njegovu radu vidi: Ivana Marasović Šušnjara i sur., Doktor Josip Škarić (1887.-1975.) - pionirski pothvati na polju javnog zdravstva na području Dalmacije u prvoj polovici 20. stoljeća. U: Acta Med Croatica, 71(2017), str. 319-326. Posebno su dramatični njegovi opisi zapuštenosti bolesnika i kuća na koje je nailazio u svom radu.

23 U organizaciji besplatne liječničke službe sudjelovala je i Ženska zadruga u Splitu. Osnovala je Savjetovalište za majke i dojenčad, gdje je besplatno primao pacijente dr. Kovačić, i Ambulatorij Mazzi za siromahe, đake i činovnike, koji je vodio dr. Petković, a koje su primale pacijente dva puta tjedno. Škola za zdravstveno promicanje također je djelovala uz Žensku zadrugu, a poslije je prenijela svoj djelokrug po manjim mjestima širom Dalmacije. Nove zdravstvene ustanove u Dalmaciji. U: Pučka prosvjeta, 1923., br. 8, str. 139 . 
kom vodom i provođenje ostalih asanacijskih radova. Zarazne bolesti širile su se općom nehigijenom i neznanjem, a tuberkuloza je bila jedna od najraširenijih socijalnih bolesti. Spoznaja o raširenosti tuberkuloze zabrinjavala je dalmatinske vlasti još u doba Austro-Ugarske Monarhije. Njezina važnost kao socijalne bolesti u Dalmaciji dolazi do izražaja nakon što su sanirane druge epidemije (kuga i malarija). Stoga je 1902. u Zadru tiskana knjižica Propisi o suzbijanju tuberkuloze, u kojoj je naveden niz propisa koje je tadašnja vlast odredila u borbi protiv tuberkuloze. Uz izravne mjere liječenja, predložen je i niz indirektnih kako bi se postigla željena svrha: ponajprije se preporučivalo poučavanje najširih slojeva nizom predavanja, člancima i drugim popularnim djelima liječnika ili drugih stručnjaka o načinu kako nastaje tuberkuloza, ${ }^{24}$ kako se suzbija i kako se treba ponašati onaj koji ima tuberkulozu, a u vezi s preventivom preporučivalo se snažnije zdravstveno prosvjećivanje: širenje popularnih medicinskih knjiga, suradnja škola, odgojnih zavoda i humanitarnih društava, prosvjetiteljska uloga štampe i uopće svih odgovornih čimbenika u pojedinoj političkoj oblasti. Štamparova je medicina od početka bila na tragu suvremenih medicinsko-preventivnih metoda liječenja u tretmanu problema tuberkuloze. Međutim, ono što ističe vrijednost Štamparove knjižice i njegova modela liječenja baš je u tome što je Štampar dobro poznavao teško ekonomsko, socijalno i kulturno stanje pojedinih sredina u Hrvatskoj, posebice hrvatskih sela, u kojima se tuberkuloza masovno širila, te je razumio ne samo uzroke bolesti nego i odnos bolesnika prema njoj (sram, prikrivanje, zapuštanje). ${ }^{25}$ Metodološka sličnost u pristupu liječenja i suzbijanja tuberkuloze ovih dviju knjižice je očita: zajedničko im je to da se u suzbijanju tuberkuloze oslanjaju, među ostalim, i na tiskane materijale kao važno sredstvo zdravstvenoga prosvjećivanja.

Treća knjiga, koja ulazi u korpus publikacija u kontinuitetu socijalno-medicinske misli o tuberkulozi i javnoga znanja u Splitu, knjiga je dr. Rafe Ferrija ${ }^{26}$ (Ston, 24. II. 1899 - Split, 22. VIII. 1969), poznatoga splitskoga ftiziologa, Tuberkuloza u Splitu $i$ asanacija grada, objavljena 1925. godine kao prvo izdanje Dispanzera za grudne bolesti u Splitu. U toj je knjizi Rafo Ferri vrlo studiozno opisao socijalne,

24 Propisi za suzbijanje tuberkuloze: otpis C.K. Ministra predsjednika kao upravljača ministarstava unutrašnjih posala, dneva 14. jula 1902. br. 29949. Zadar 1902. U vezi s indirektnim mjerama, Ministarstvo preporučuje: »To je prije svega poučavanje najširih slojeva pučanstva o načinu kako postaje i kako se suzbija tuberkuloza i kako se čovjek ima vladati kad je zdrav i kad oboli. To se može postići s popularnim predavanjima i člancima liječnika ili kojih strukovnjaka i širenjem dobrih popularnih djela za koje bi se imala postarati humanitarna društva«, str. 13.

${ }^{25}$ O stanju zdravlja i teškim uvjetima života u Splitskoj oblasti nakon teške zime vrlo potresnu izjavu dao je liječnik Ivo Petković, govoreći o strašnoj gladi od koje posebno pate djeca, nestašici novca i pitke vode: Zdravstveno stanje u Splitskoj oblasti. Novo doba, (1929), br. 102, str. 5.

26 Rafo Ferri: Tuberkuloza u Splitu $i$ asanacija grada, Split 1925. Opširnije o Rafi Ferriju vidi u: Zaslužni splitski liječnici u prošlosti od 1946. do 1947., Split 1999., str. 56-71. 
preventivno-higijenske te institucionalne probleme s kojima se susreće Split u borbi protiv tuberkuloze. Početkom XX. stoljeća tuberkuloza je bila raširena u cijelom Splitu, pa je Ferri izradio kartu predjela u kojima je najraširenija i na taj način dao putokaz za regulaciju i asanaciju gradskih predjela. Opisao je ostvarene i potrebne asanacijske radnje te izradio »vodič« prirodnih prednosti Splita za boravak u prirodi i zdrav život. Ta je knjižica bila namijenjena stručnoj javnosti, ali donosi niz zdravstvenih preporuka i prednosti Splita koje mogu olakšati borbu protiv tuberkuloze, koje su razumljive i intelektualnoj javnosti grada koja se kroz humanitarna društva i na drugi način može boriti protiv te opake bolesti. Statistički je prikazao i kretanje broja umrlih od tuberkuloze (u postotcima općega pomora i prema broju stanovnika) kao ilustraciju relativnoga uspjeha u liječenju. ${ }^{27}$ Osnovni čimbenici, koji po njemu djeluju na javno zdravlje, posebno posljednjih godina, ekonomsko su stanje pojedinaca, nehigijenski uvjeti stanovanja, posebice u pojedinim dijelovima Splita (Dioklecijanova palača, Veli Varoš, Radunica) i uopće nehigijena. Analizirao je gradske napore za asanaciju grada, uređenje ulica, proširenje vodovodne mreže i sl. te mogućnosti institucionalnoga liječenja. U Splitu je 1923. osnovan Dispanzer za grudne bolesti koji je obavljao velik broj pregleda, ali je bolnica imala nedovoljan broj kreveta i za druge bolesnike i nije imala poseban odjel za liječenje tuberkuloznih bolesnika. Pitanje sanatorija bilo je otvoreno. Prema njegovoj procjeni svaka trideseta osoba boluje od tuberkuloze, a umire oko stotinjak ljudi, većinom mlađih. Podatci koje je iznio splitskoj su javnosti jasno pokazali kakav je problem tuberkuloza, senzibilizirali su javnost i postali dio javnih spoznaja pred kojima se nije moglo »zatvoriti oči«, što nije pokrenulo medijsku kampanju, ali je produbilo svijest i poglede na tuberkulozu te zasigurno produktivno utjecalo na kasniju medijsku proizvodnju članaka.

\section{Splitski časopis Pučka prosvjeta u borbi za suzbijanje tuberkuloze između dvaju ratova: početak kampanje}

Osnivanjem Ministarstva za narodno zdravlje (poslije Ministarstva narodnoga zdravlja i socijalne politike) i organizacijom zdravstvene službe započela je nova zdravstvena politika i omogućeno je smišljeno i organizirano njezino provođenje u Kraljevini SHS, u čemu je aktivno sudjelovao i Andrija Štampar. Zdravstveni odsjek za Dalmaciju, osnovan 1919., odmah po osnutku započeo je s edukacijom liječnika u

27 Ibid., str. 20. U svojoj brošuri o tuberkulozi R. Ferri iznio je statistiku umrlih od tuberkuloze u odnosu na »opći pomor«, ustvrdivši da je u 25 godina od tuberkuloze umrlo 2718 osoba, od kojih $75 \%$ od plućne tuberkuloze. Prikazao je statističke pokazatelje umrlih od tuberkuloze od 1900. do 1924. Godine 1900. umrlih od tuberkuloze bilo je $16,69 \%$ te se krivulja postotaka od tada kretala uzlazno i silazno da bi 1924. taj postotak iznosio $14,67 \%$. U relaciji prema broju stanovnika taj je postotak 1900. iznosio $6,36 \%$, a 1924. godine 3,74\%, što pokazuje smanjivanje krivulje kao rezultat djelovanja zdravstvenih ustanova. Ibid., str. 9. 
suočavanju s tuberkulozom. Započela je i šira kampanja zdravstvenoga prosvjećivanja u časopisima i novinama, osnovano je Društvo za borbu protiv tuberkuloze te Liga za borbu protiv tuberkuloze Primorske banovine, što je, uz rad liječnika, omogućilo i uključivanje građanstva kroz dobrotvorni rad. Tuberkuloza je na taj način postala javno vidljiva bolest, bolest koja je iz sfere pojedinca i obitelji postala javnozdravstveni problem. Osim knjigama i brošurama, Splićani su bili obavještavani i educirani o socijalno-higijenskim problemima tuberkuloze, metodama liječenja i uspjesima zdravstvene službe u popularnim časopisima i novinama te drugim sredstvima propagande: plakatima i prigodnim letcima, predavanjima i izložbama.

Početak medijske kampanje možemo pratiti već od 1920., kad su, kako je zabilježilo Novo doba održani tečajevi za usavršavanje liječnika u organizaciji Zdravstvenoga odsjeka za Dalmaciju. Predavanja su bila iz područja socijalne medicine, bakteriologije, epidemiologije, tuberkuloze i drugih zaraznih bolesti. ${ }^{28}$ Sljedeće, 1921. godine zabilježeno je i da su u kinu Karaman prikazana četiri propagandna filma o tuberkulozi koja je publici komentirao dr. Šime Ljubić. ${ }^{29}$ Obavještavanje o djelatnosti Zdravstvenoga odsjeka, predavanjima, izložbama i sl. nastavljeno je u novinama i dalje. Zdravstveni odjel organizirao je u ožujku 1922. antialkoholnu i antituberkuloznu izložbu u svojim novim prostorima, aktivno provodeći zdravstvenu edukaciju na tragu ideja A. Štampara. U dvije velike prostorije izložen je velik broj slika, plakata i tablica o štetnom djelovanju tuberkuloze i alkohola. Liječnici Zdravstvenoga odjela u Splitu objašnjavali su posjetiocima izložene materijale..$^{30}$

U promociju djelovanja higijensko-zdravstvene službe u sprječavanju tuberkuloze vrlo rano se uključio popularni opći prosvjetni časopis Pučka prosvjeta. ${ }^{31}$ Već 1921. dr. Josip Arambašin objavio je članak »Korist učenja higijene «, ${ }^{32}$ na tragu pro-

28 Novo doba, 3(1920), br. 264, str. 3 (22.11.); U Zagrebu je 1919. osnovano Povjerenstvo za suzbijanje tuberkuloze. U svom programu ističu: »Potrebno je da se naša javna štampa, a naročito periodični časopisi, sistematski upućuju u suzbijanje tuberkuloze ...Osim te periodične propagande, trebat će izdavati i priručnike za liječnike, medicinare, školske knjige i štiva i napokon sasma popularnu uputu za široko općinstvo...«. Željko Dugac: Zdravstveno prosvjećivanje protiv tuberkuloze, Medicus, str. 157.

${ }_{29}$ To su »Tuberkuloza uopće«, »Staralište za tuberkulozne«, »Škola na suncu za slabunjavu djecu« i »Sanatorij na Brestovcu«. Novo doba, 4(1921), br. 5, str. 3 (8. I.).

30 Novo doba, 5(1922), br. 60, str. 3 (14. III.)

31 U Splitu je postojala tradicija izdavanja pučkih listova. Časopis Pučka prosvjeta izlazio je kao mjesečnik od 1921. do konca 1932. Bio je opći prosvjetni časopis koji je na neki način nastavljao tradiciju pučke prosvjete časopisa Pučki list, što ga je također uređivao don Frane Ivanišević. Između dvaju ratova to je bio jedini časopis za pučko prosvjećivanje koji je radio na podizanju kulturne razine svojih čitatelja i na održavanju veza s Hrvatima izvan domovine.

32 Pučka prosvjeta, 1921, br. 5 (maj), str. 68-69. J. Arambašin tuberkulozi pristupa kao činjenici koja ima negativne posljedice i na ukupni ekonomski razvoj države. Preračunato u financijske pokazatelje, pokazuje štetne posljedice neliječenja od tuberkuloze. Na kraju članka naglašava ciljeve zdravstvene politike: »Eto za tim ide nauka o zdravlju: ona hoće da svaki naš čovjek dođe do znanja i do uvjerenja da 
filaktičkih, socijalno-higijenskih preporuka A. Štampara. Broj 8 iz 1923. posvećen je gotovo u cijelosti narodnom zdravlju. U nepotpisanom uvodniku, koji je vjerojatno napisao dr. Josip Arambašin, naglašava se da je cilj toga broja »da podučimo naš narod, osobito po selima kako mu je čuvati ovo blago što mu ga je Bog dao, ...stara je besjeda od davnih mudraca: u zdravom tijelu i pamet je zdrava«. Don Frane Ivanišević, urednik Prosvjete, kao župnik u Jesenicama imao je doticaj s narodom, poznavao je njegove potrebe, znanje o bolesti i racionalnom životu, bio je u prilici besplatno dijeliti časopis na čitanje. Članci objavljeni u tom broju pokazatelj su liječničkih napora za ostvarenje ideala narodnoga zdravlja A. Štampara. Opširnije članke o različitim dijagnostičko-terapeutskim i higijenskim problemima zaraznih bolesti objavili su Vjera Škarica, ${ }^{33}$ Josip Arambašin, Branko Peričić, ${ }^{34}$ F. D. Marušić, ${ }^{35}$ A. Sfarčić pisao je o suzbijanju malarije, Ivo Stalio o spolnim bolestima te Josip Berković, ${ }^{36}$ liječnici u službi pojedinih odsjeka zdravstvene službe u Splitu. U svojim člancima pisali su jasno i razumljivo, bez pretjerane uporabe stručnih termina, pristupačno svim čitateljima, pa i onima koji su bili manje pismeni. Pokazali su senzibilitet za zdravstvene probleme, poznavanje stvarnoga ekonomskoga stanja i uvjeta života siromašnih u Splitu i okolnim selima, razumijevanje da uspjeh u borbi protiv zaraznih bolesti, osobito tuberkuloze, nije samo medicinsko-terapeutski problem nego prije svega ovisi »od asanacije socijalnih prilika, posebno od bolje prehrane«, zdravstvenoga prosvjećivanja te o mogućnosti stvaranja bolničkih kapaciteta za izolaciju bolesnih.

Pučka prosvjeta 1925. objavljuje oveći članak dr. Josipa Škarića, bliskoga suradnika Andrije Štampara od prvih dana djelovanja javnoga zdravstva u Splitu, o radu Državne bakteriološke stanice, otvorene 1. ožujka 1922. Naveo je zapanjujući podatak da se do njezina osnivanja krv na pregled slala u Beč ili Trst, a sada je to bilo moguće u Splitu. Na kraju članka naglasio je zasluge A. Štampara koji je dao »temelj i smjer«

sve što potroši za poboljšanje zdravlja naplati mu se s velikom kamatom i da nauči kako se do toga dolazi...«.

33 Vjera Škarica u članku »Prva hrana i dojenje« obraća se majkama, ističući vrijednost majčina mlijeka kao hrane. »Majčina je dakle dužnost da doji svoje dijete ako joj je ikako moguće jer se majčino mlijeko i srce ne daju nikako zamijeniti.« Pučka prosvjeta, br. 8, 1923., str. 118-119.

34 Branko Peričić u članku »Higijena stana« piše o svim važnim elementima higijene stana i kuće. Nikakva kuća, makar najbolje uređena, drži on, ne može se smatrati higijenskom ako se ne drži čistom. Pučka prosvjeta, 1923., br. 8, str. 125-127.

$35 \mathrm{U}$ članku »Djeca na moru« ističe se ljekovitost morske kupelji protiv mnogih bolesti, pa i tuberkuloze, kao poziv moderne znanosti »povratite se prirodi«. Pučka prosvjeta, 1923., br. 8, str. 124-125.

36 U članku »Tuberkuloza i prehrana« osvrće se na podatke o umiranju od tuberkuloze. »Politički kotar Split sa nešto više preko 100.000 duša imao je do g. 1919. godišnje preko 200 smrti od tuberkuloze«, piše on. Nakon rata tuberkuloza nije posustala zbog »oskudijevanja i stradanja za vrijeme rata te nemogućnost da se kroz tako kratko vrijeme osjetljivo stane na put tako velikom zlu, pošto svaki i manji napredak na tom polju iziskuje ogromnih materijalnih žrtava...«. Pučka prosvjeta, 1923., br. 8, str. $133-134$. 
socijalno-zdravstvenoj organizaciji u Kraljevini SHS. ${ }^{37}$ Josip Berković se u članku »Borba protiv sušice (tuberkuloze)« osvrće na uzroke bolesti koje također vidi u ekonomskim prilikama bolesnika te iznosi nekoliko podataka o poduzetim mjerama koje su terapeutske, higijenske i propagandne. Liječnici su u profilaksi i prevenciji tuberkuloze obavljali golem posao; od 1. VIII. 1923. do 31. XII. 1924. pregledali su 4184 novih bolesnika i otkrili 2506 slučajeva tuberkuloze, od kojih je $12 \%$ s otvorenim procesom. Obišli su 1662 kuće i upoznali se sa stvarnim higijenskim uvjetima stanovanja, dijelili materijalnu pomoć i pomoć u hrani, podučavali stanovništvo i podijelili 7495 letaka. $^{38}$

To su bili prvi propagandni koraci splitskih liječnika i dispanzerske službe, ${ }^{39}$ kojima je započelo zdravstveno prosvjećivanje, informiranje i stvaranje javnoga znanja o stanju te bolesti. Tuberkuloza je, kao bolest od koje se umiralo, izazivala strah u stanovništvu zbog neznanja o tome kako se prenosi i razvija te kako se treba odnositi prema tuberkuloznom bolesniku. Sve veći strah od tuberkuloze naveo je Branka Nižetića da u članku »Tuberkuloza i općenite predrasude o njoj « ${ }^{40}$ objašnjava da je osnovni problem u stvaranju nekih predrasuda o tuberkulozi neznanje koje podržava strah od zaraze. Svoj članak završava s nekoliko propisa o čuvanju od zaraze koje ulaze u korpus općenitih higijenskih preporuka.

\section{Uloga lokalnih novina u kampanji za suzbijanje tuberkuloze}

U obavještavanje šire javnosti o tuberkulozi između dvaju ratova uključile su se u velikoj mjeri i lokalne novine i razvile široku kampanju zdravstvenoga prosvjećivanja javnosti i informiranja o radu zdravstvene službe i statističkim pokazateljima u borbi protiv tuberkuloze. Analizirali smo napise u Novom dobu (1918-41) i Fadranskom dnevniku (1934-38), kao najznačajnijim novinama iz toga razdoblja koje su izlazile u Splitu. Na tragu Štamparovih uputa o promicanju socijalnih, higijenskih i

37 „Čitava pak zdravstvena organizacija je tako uređena da su se prvi svjetski ljekarski stručnjaci, a osobito Amerikanci izrazili da smo na tom polju pretekli sve po ratu nastale kao i mnoge od starih država. Za taj ogroman napredak ide u prvom redu zasluga načelnika Ministarstva narodnog zdravlja gosp. Prof. Štampara koji je dao temelj i smjer cjelokupnoj našoj socijalno-zdravstvenoj organizaciji«, Pučka prosvjeta, 1925., br. 6, str. 96-98.

38 Pučka prosvjeta, 1925., br. 3, str. 48-50.

39 Andrija Štampar posebno je naglašavao ulogu dispanzera već 1919. godine: »Glavna nam je zadaća osnivanje dispanzera za tuberkulozu, koji će nam otkriti sva vrela zaraze i omogućiti jedino ispravno socijalno djelovanje. Ti će dispanzeri ispitivati sve odnošaje jednog tuberkuloznog bolesnika, provađati njegovu izolaciju u kući, potpomagati njegovu obitelj sanitarno i materijalno, vodit će brigu o higijeni stana i na taj način sprečavati familijarnu infekciju.« Andrija Štampar: O zdravstvenoj politici. U: U borbi za narodno zdravlje: izabrani članci Andrije Štampara, str. 69.

40 Branko Nižetić: Kalendar »fadran«, 1928., str. 70-73. 
zdravstvenih mjera borbe za suzbijanje tuberkuloze, novine su imale važnu funkciju jer su obavljale masovnu difuziju (prijenos, širenje) različitih informacija. Ta dva dnevnika objavila su tijekom dvadesetak godina vrlo velik broj članaka različitih novinskih žanrova (vijesti, osvrta, saopćenja, prikaza, intervjua) ${ }^{41}$ koji su obavještavali splitske čitatelje o svim temama iz područja zdravstvenoga prosvjećivanja i promicanja borbe za suzbijanje tuberkuloze, izravno promičući tu temu ili kontekstualno $\mathrm{u}$ vezi s brojnim gradskim socijalnim problemima. Svakako se radilo o medijskoj regulaciji stvarnosti i djelovanja građana s pozitivnim učinkom. Nije nam poznato jesu li se i u drugim sredinama lokalne novine uključile u kampanju u takvim razmjerima, ali angažman splitskih novina na saniranju teškoga socijalno-zdravstvenoga problema zasigurno zaslužuje pozornost. Informativno-političko novinstvo bilo je razvijeno u Splitu još na prijelazu dvaju stoljeća. Nakon 1918. pokrenuto je Novo doba, političko-informativni list, ${ }^{42}$ a poslije i još neki dnevnici koji su kraće izlazili, a među kojima se posebno ističe fadranski dnevnik, dubinski zahvaćajući brojne gradske kulturne i društvene probleme. ${ }^{43}$ Ova su dva dnevnika regulirajućom diskurzivnom praksom dovela tuberkulozu u fokus javnosti. Novine su uvijek dio neke organizirane društvene prakse, informiranja, propagiranja, zastupanja i sl. Neovisno o Baudrillardovoj kritici komunikacijskoga modela kao »modela simulacije komunikacije«, činjenica je da su novine kao masovni mediji učinili da je tuberkuloza, koja je prije Prvoga svjetskog rata većinom imala sporedni status, a njezino liječenje bilo privatna obveza, postala predmet neprekinuta zanimanja i javni društveni problem i obveza. Sad je tuberkuloza, nekad bolest na margini javnoga interesa, »zadobila veliku difuzijsku moć što (joj) podaruje društvene i 'historijske' razmjere« ${ }^{44}$ Ona je naime nadišla značenje »gradske rubrike« i postala »moćna« tema forsirane medijske kampanje. Novine imaju moć nametnuti temu i postaviti ju na »dnevni red«; one su je učinile

41 Radi se doista o velikom broju članaka, od kojih smo odabrali samo neke kako bismo ilustrirali osnovnu temu rada. U svojoj ukupnosti svi ti tekstovi potvrđuju našu osnovnu tezu da su lokalne novine imale snažnu i još nedovoljno prepoznatu ulogu u procesu informiranja i zdravstvenoga prosvjećivanja stanovništva.

42 Opširnije o Novom dobu vidi u: Ivanka Kuić: Kulturna baština, 39(2013), str. 113-138.

43 Između dva rata prema bibliografiji Hrvoja Morovića izlazila su 122 naslova novina s manjim ili dužim vremenom izlaženjem. Velik broj naslova dolazio je iz različitih diskursnih sfera: zastupale su političke stranke, interese pojedinih društvenih grupa i slojeva - radnika, činovnika, pomoraca, sportske, kulturne i religijske teme, donoseći u javnost mnoštvo društvenih praksi i uvodeći Split u moderno društvo u kojem se zrcali niz problema. Novo doba i fadranski dnevnik, kao i sve druge novine, danas su dokumenti života i transformacije Splita u moderan i otvoren grad.

44 Jean Baudrillard: Simulacija $i$ zbilja, Zagreb 2013., str. 56-78. Navodimo ovom prilikom kao važno mišljenje Stuarta Halla o komunikaciji putem medija: Hall drži da se o modelu komunikacije razmišlja linearno, ali da ga je moguće promatrati i kao strukturu »koja nastaje i održava se artikulacijom povezanih, ali odvojenih momenata proizvodnje, kruženja, distribucije, potrošnje, reprodukcije«. To znači da se taj proces održava artikulacijom povezanih praksi i da je potrošnja ili recepcija poruke i sama jedan trenutak proizvodnoga procesa u širem smislu. Stjuart Hol: Mediji i moć, str. 7-11. 
konfliktnom i kontinuirano politički zanimljivom u okviru zdravstvene politike koja se provodila u Kraljevini SHS/Jugoslaviji, sudjelujući u procesu njezine socijalizacije i demokratizacije, dajući širu sliku o tim procesima i zadobivajući moć da predstavljaju i upravljaju društvenom stvarnosti. ${ }^{45}$ Danas je to zabilježeno znanje historijska činjenica iz koje zaključujemo kako se Split kao zajednica odnosio prema tom najvećem »društvenom zlu« ${ }^{46}$

Splitski liječnici koji su »s velikom ljubavlju, požrtvovanjem, jednom novom ideologijom žilavo radili zadnjih pet godina $\ll^{47}$ na suzbijanju tuberkuloze nisu bili vezani samo uz časopis Pučka prosvjeta. Bili su svjesni važnosti medijske promocije problema. Godine 1929. objavljen je intervju s liječnikom Rafom Ferrijem, voditeljem Dispanzera za grudne bolesti, o radu dispanzera i uspjesima u liječenju tuberkuloze. Tada je istaknuto da u Splitu godišnje umire oko 75 bolesnika od tuberkuloze pluća, a to znači da ima oko 550 oboljelih, te da je taj broj zasigurno još veći jer ima dosta naoko zdravih ljudi s prikrivenom latentnom bolešću. Ipak se u borbi s tuberkulozom smrtnost posljednjih godina smanjuje. Tako je prosječni mortalitet od tuberkuloze u Splitu oko 3\% ${ }^{48}$

Nalazimo još nekoliko njihovih članaka iz područja kojim su se bavili: dr. Stevan Simunović (voditelj Socijalno-medicinskoga odjeljenja Higijenskoga zavoda) bavio se higijenom prehrane i napisao članak »Problemi ishrane naših sela« koji je tiskan neposredno prije prvoga sastanka Lige protiv tuberkuloze Primorske banovine, osnovane 1931., koja je imala 62 člana. Pozivajući na mobilizaciju cijeloga naroda i države u borbi protiv »podmuklog i upornog neprijatelja«, zaključuje da »oskudica higijene, racionalnog rada, dovoljne ishrane i kulturnog shvaćanja sa svojim neha-

45 Svakako treba napomenuti da je Split prije Prvoga svjetskog rata bio socijalno snažno podijeljen grad, što je bio dio njegova tadašnjega identiteta. Nakon rata i zahvaljujući gradskoj upravi, njegovi se dijelovi sve više povezuju i socijaliziraju. U svemu tome su i lokalni mediji imali velike zasluge prenoseći novi doživljaj grada kao cjeline svojim čitateljima. Tuberkuloza tako postaje gradski problem, a ne problem njegovih siromašnih dijelova, što se vidi iz brojnih izvješća sa sastanaka i skupština njegovih upravnih tijela.

$46 \mathrm{U}$ teoriji medija postoji obiman katalog funkcija koje autori pridjeljuju masovnim medijima u različitim periodima. Velik broj autora podržava tezu da »masovni mediji uvijek poprimaju oblik i kolorit određenih društvenih i političkih struktura«. Za ovaj rad mogli bismo se pozvati na Harolda Laswella, koji zastupa mišljenje da je funkcija medija: 1) promatranje i kontrola okruženja, 2) uspostava odnosa između dijelova društva kao reakcija na zahtjev okruženja i 3) prijenos kulturne baštine na sljedeću generaciju. U cjelini to je stabiliziranje sustava masovne komunikacije. U: Michael Kunczik, Astrid Zipfel: Uvod u znanost o medijima i komunikologiju. Zagreb, 2006., str. 37.

47 Andrija Štampar: Pet godina socijalno-medicinskog rada u Kraljevini Srba, Hrvata i Slovenaca 1920-1925. U: U borbi za narodno zdravlje, str. 96.

48 Tuberkuloza u Splitu. Novo doba, 1929., br. 207, str. 2 (23. VIII.) 
jem, stvaranju povoljne uvjete za širenje socijalnih bolesti a posebno tuberkuloze «. ${ }^{49}$ Napisao je i opširni članak o prvoj higijenskoj izložbi organiziranoj u Beogradu 1933. u kojem je opisao izložbe pojedinih odsjeka: za tuberkulozu, malariju i druge zarazne bolesti, higijenu, zaštitu majke i djeteta i $\mathrm{dr}^{50}$

Dr. Smiljana Antunović-Mikačić, voditeljica Bakteriološko-epidemiološkoga odjeljenja Higijenskoga zavoda, obraća se izravno ženama u članku »Žene i tuberkuloza ${ }^{51}$ Polazeći od toga da je $» j$ edino dobro bezimena čovjeka radna snaga $i$ zdravlje« sasvim nezaštićena od socijalnih bolesti, ona se obraća ženama s nekoliko preporuka kako zaštititi djecu i obitelj jer žene mogu spriječiti širenje tuberkuloze zaštitom djece od bolesnika, cijepljenjem, brigom o higijeni, o hrani, nadzorom kontakta djece s osobljem koje može biti bolesno, aktivnim zalaganjem za uređenje grada, škola, parkova i jačanjem, s porukom »Mi žene - polovica čovječanstva, bez obzira na naš položaj i zvanje, jer naša su nam djeca jednako mila, pokažimo shvaćanja za ovakve akutne probleme naše najbliže okoline i surađujmo na njemu aktivno«. Vrlo opširan članak »Socijalno higijenska zaštita majke i djeteta«, koji nije izravno povezan s tuberkulozom, navodimo kao primjer svijesti o potrebi zdravstvenoga prosvjećivanja žena koje su čuvarice obiteljskoga zdravlja. Ona piše o modernim metodama zaštite majke i djece u svijetu; osvrće se na stanje u Splitu i rad tradicionalnih ustanova socijalne skrbi koji nije zadovoljavajući. Iznosi podatke o mortalitetu djece u splitskom kotaru u 1927. koji iznosi 35\%. ${ }^{52}$

Ljubo Šimunić u antituberkuloznom tjednu u članku »Oboljenje i borba protiv tuberkuloze kod djece i odraslih « ${ }^{53}$ jednostavno i poučno objašnjava povijest, etiologiju i obilježja tuberkuloze kao zarazne bolesti te kako se ona prenosi na djecu koja vrlo lako obolijevaju od nje. Drži da samo zdravstvenim prosvjećivanjem nije mogu-

49 Novo doba, 15(1932), br. 16, str. 3-4 (subotnji prilog, 16. I.). U svom članku dr. Simunić tvrdi: »Našu državu u 10 godina tuberkuloza je koštala preko pola milijuna grobova i preko stotinu milijardi dinara«. Pitanje ishrane pasivnih krajeva, nezaposlenosti radnika i socijalno osiguranje postaje predmet rasprave socijalne sekcije poslaničkog kluba sa zaključkom da se rasprava proširi na parlamentarni klub. $\mathrm{U}$ istom broju na naslovnoj stranici objavljeno izvješće sa sjednice. (19. VIII.)

50 Stevan Simunić. Velika higijenska izložba u Beogradu. Novo doba, (1933), br. 193, str. 11

51 Fadranski dnevnik, 2(1935), br. 122, str. 3 (25. V.). S. Antunović-Mikačić naglašava, kao i svi liječnici, teške socijalne prilike u kojima žive pojedine obitelji, osobito one koje imaju bolesnika. Za ilustraciju teškoća u borbi s bolešću navodi podatke iz tromjesečnog izvještaj Antituberkuloznoga dispanzera u Splitu za 1935: od bolesnika s otvorenim procesom tuberkuloze,73 bolesnika imala su zasebnu sobu, 58 bolesnika bilo je s odraslima u sobi, 10 bolesnika bilo je s odraslima u krevetu, a 19 bolesnika bilo je $s$ maloljetnom djecom u sobi.

\footnotetext{
52 Novo doba, 12(1929), br. 160, str. 7-8 (27. VI.)

53 Novo doba, 18(1935), br. 120, str. 3 (23. V.)
} 
će riješiti ovaj problem ako pritom nedostaje dovoljan broj kreveta u bolnicama i sanatorijima, kao što je to bio slučaj u Splitu.

Novine su i 1930-ih godina nastavile bilježiti teme iz svih područja socijalne medicine: izvještaje o narodnom zdravlju, zdravstvenom prosvjećivanju, prevenciji, etiologiji tuberkuloze, djelatnosti medicinskih ustanova u području liječenja i zaštite od bolesti i statističke pokazatelje Dispanzera za grudne bolesti, Higijenskoga zavoda i Zdravstvenoga odsjeka grada Splita, promotivne aktivnosti, primjerice Antituberkulozni tjedan, koji su svake godine organizirali Društvo za borbu protiv tuberkuloze i Higijenski zavod, u okviru kojega su držana predavanja, prikazivani filmovi i dijeljeni letci o zaštiti od bolesti i liječenju. Svi članci osim što su širili znanje o higijeni i bolesti objavljivanjem statističkih pokazatelja upozoravali su na opasnost od bolesti.

U članku o izvješću Dispanzera za grudne bolesti za $1933 .{ }^{54}$ naglašena je važnost profilakse koju provode medicinske institucije. Redakcija je zamolila da Dispanzer dostavi podatke o radu u desetogodišnjem razdoblju te podatke o zaraznim bolestima za 1932: Dispanzer je u toj godini imao velik broj pregleda bolesnika i 150 diskretno registriranih bolesnika od tuberkuloze, a pretpostavka je da ih ima oko 300 jer se svi ne prijavljuju i nije obvezna prijava bolesti od tuberkuloze; umrla su 72 bolesnika od plućne tuberkuloze. Opisane su i druge aktivnosti, posjeti kućama, napori za odvajanje bolesnih i zdravih, dijeljenje materijalne pomoći i sl. U tekstu se osjeća snažna senzibiliziranost autora i redakcije za prilike u kojima žive pojedine siromašne obitelji.

Redovito je praćen rad gradskoga Zdravstvenog odsjeka, koji je primjerice 1934. u raspravi o stanju zdravlja u gradu i poduzimanju higijenskih mjera, prema izvješću tadašnjega šefa saniteta dr. Mihovila Čulića, naglasio da je u gradu velik broj zaraznih bolesti, posebice od tuberkuloze, a samo tijekom listopada 1934. od raznih oblika tuberkuloze umrlo je 12 osoba. ${ }^{55}$ Tuberkuloza je najčešće u člancima označavana kao »naše najveće socijalno zlo«. Kao najveći problem označavani su higijena stana i nedostatak dovoljnoga broja bolničkih kreveta za izolaciju bolesnika. Bolesnici zbog siromaštva ostaju u obitelji, truju sve oko sebe i »u velikom broju slučajeva i vlastitu malenu djecu«. Međutim, stanje se u Splitu ne popravlja. Izvještaj sa sjednice Odsjeka u siječnju 1939. o zaraznim bolestima pokazuje da tuberkuloza kao socijalno zlo ne posustaje. Naime u 1938. registrirano je 297 bolesnika (moguće kao rezultat doseljavanja). Tom je prilikom istaknuto da liječenje jednoga tuberkuloznog bolesnika košta između 10 i 20 tisuća dinara. Kao tri temeljna uvjeta za suzbijanje tuberkuloze istaknuta je higijena, nedostatak tuberkuloznoga odjeljenja i prehrambene prilike. ${ }^{56}$

54 Tuberkuloza u Splitu. Novo doba, 16(1933), br. 79, str. 6 (4. IV.)

55 Porast pučanstva u III. tromjesečju ove godine, fadranski dnevnik, 3(1936), br. 232, str. 5 (18. XII.); vidi i Sjednica općinskog zdravstvenog odbora. Novo doba, 17(1934), br. 163, str. 5 (13.VII.)

56 Naše najveće zlo je tuberkuloza. Novo doba, (1939), br. 17, str. 3 (20. I.) 
Redakcija Novoga doba donosila je i obavijesti Ministarstva socijalne skrbi i narodnoga zdravlja. Primila je zamolbu Odsjeka za suzbijanje tuberkuloze pri Ministarstvu socijalne skrbi da redovito objavljuje vijesti o broju slobodnih kreveta u lječilištima te vijesti koje o tuberkulozi dostavlja Agencija Avala. Državne strukture prepoznale su potrebu angažiranja sredstava masovne komunikacije u široj difuziji informacija i znanja o stanju tuberkuloze i njihovu moć oblikovanja i reguliranja javnoga ponašanja. Prilikom osnivanja Jugoslavenske lige za borbu protiv tuberkuloze novine su objavile propagandni članak o glavnim zadatcima borbe protiv tuberkuloze. Po nalogu Ministarstva socijalne skrbi i narodnoga zdravlja održana je u Splitu anketa o prijavi bolesnika od tuberkuloze. To je bila dvodnevna rasprava u kojoj su sudjelovali liječnici koji neposredno djeluju u zaštiti od tuberkuloze. Raspravljalo se o prednostima i posljedicama obvezne prijave pa je zaključno da bi se obvezna prijava, zbog različitih kulturnih i socijalnih problema, mogla uvesti samo u sredinama koje imaju dispanzere i kod liječnika koji besplatno liječe, ali ne i kod privatnih liječnika. ${ }^{57}$ Prenijeli su priopćenje Ministarstva o tuberkulozi kod djece i u 12 točaka kako se može prepoznati simptome tuberkuloze kod male djece. ${ }^{58}$ Tijekom antituberkuloznoga tjedna Dispanzer za grudne bolesti tiskao je nekoliko tisuća letaka i razaslao ga po cijeloj banovini. Tekst letka objavljen je u cijelosti..$^{59}$ Objavljen je i velik članak o glavnim zadacima borbe protiv tuberkuloze u povodu osnivanja Jugoslavenske borbe protiv tuberkuloze. ${ }^{60}$ Tuberkulozu se povezivalo i s književnim djelima i sudbinama književnih junaka, sportom i drugim područjima socijalnih praksi. Praćenje statističkih pokazatelja o broju oboljelih od tuberkuloze nastavljeno je sve do konca opisanoga razdoblja. Mnoga područja Splita bila su rasadište nehigijene i zaraze. U članku »Pred vratima Splita« upozorava se vlast kako se živi u splitskoj okolici i u kakvim žalosnim ekonomskim i higijenskim uvjetima žive splitski radnici. Naglašava se nastojanje Društva za suzbijanje tuberkuloze, kao i drugih društava, da pomognu bolesnima. U sklopu svojih aktivnosti Društvo je dijelilo plakate po gradu sa sljedećim sadržajem: »Svaki četvrti čovjek umire kod nas od sušice. Kad kašlješ, drži rupčić na ustima«. ${ }^{61}$

57 Anketa radi obvezne prijave tuberkuloze. Novo doba, 18(1935), br. 46, str. 6 (23. II.)

58 Borba protiv tuberkuloze. Fadranski dnevnik, 2(1935), br. 81, str. 5 (5. V.)

59 Čuvajte se tuberkuloze. Fadranski dnevnik, 2(1935), br. 121, str. 5 (24. V.)

60 Glavni zadaci borbe protiv tuberkuloze: povodom osnivanja Jugoslovenske lige za borbu protiv tuberkuloze, Novo doba, 15(1932), br. 95, str. 4 (23. IV.)

${ }_{61}$ Fadranski dnevnik, 1(1934), br. 53, str. 4 (23. V.). Naglašavaju se postignuća gradskih vlasti u rješavanju stambenih problema radnika u pojedinim dijelovima Splita, ali se istodobno upozorava na nove takve probleme. 


\section{Društvo za borbu protiv tuberkuloze u Splitu}

Društvo za borbu protiv tuberkuloze osnovano je na tragu prakse koja je već uvelike postojala u razvijenim zemljama Europe i na tragu preporuka Andrije Štampara. Nešto ranije takvo je društvo osnovano u Zagrebu. U travnju 1931., prema napisima u Novom dobu, u krugu liječnika koji su radili oko Higijenskoga zavoda odlučili su osnovati Društvo za borbu protiv tuberkuloze, što je značilo uključivanje širega građanstva u humanitarnu borbu protiv ovoga društvenoga problema. Promicatelini odbor sastavio je proglas i razaslao ga na brojne adrese. U letku je stanovništvo upozoreno na opasnost od tuberkuloze u svijetu i u Primorskoj banovini, u kojoj godišnje od nje umire oko 2000 ljudi. ${ }^{62}$ Prema opširnom izvješću s prve godišnje skupštine Društva, predsjednik Josip Arambašin, istaknuo je da je Društvo, s malim sredstvima od 9000 dinara, nemoćno učiniti više od zagovaranja podizanja »za slabunjavu djecu škole na otvorenom, u prirodi« i to pod uvjetom da bude potpomognuto državnim sredstvima i da i dalje promiče zdravstveno prosvjećivanje i zdravstveni odgoj. Prema izvješću Rafe Ferrija, Društvo je imalo 456 članova u Splitu. Namjeravali su proširiti članstvo u i drugim sredinama. U godinu dana rada ipak su »udareni ... temelji za osnivanje jačeg fonda za suzbijanje tuberkuloze«. Zajedno s Higijenskim zavodom organiziran je tjedan borbe protiv tuberkuloze, a s namjerom da se ta akcija pokrene i u sljedećim godinama. Osim predsjednika Josipa Arambašina, potpredsjednika Josipa Škarića, tajnika Rafe Ferrija, blagajnika Mihovila Čulića, u upravi Društva bila je kao potpredsjednica i Eleonora Tartaglia, supruga bana Ive Tartaglie, što je obećavalo novinsko praćenje rada Društva. U odbor Društva izabrani su i drugi ugledni Splićani iz redova liječnika, učitelja, ravnatelja škola i drugih ustanova. ${ }^{63}$ Na skupštini održanoj 1935. istaknut je rad Društva na osnivanju šumske škole na Marjanu, izgradnji dječjega igrališta i privremenoga bolničkoga paviljona za tuberkulozu u blizini nove bolnice. ${ }^{64}$ Na skupštini održanoj 1936., na kojoj je ponovno birana ista uprava, istaknuto je da je rad Društva bio većinom usmjeren prema stvaranju fondova za izgradnju antituberkuloznoga dispanzera; sredstva su položena kod Hipotekarne banke i mogu poslužiti u tu svrhu, ako do izgradnje dođe. Društvo je pokušalo doći do privremenoga paviljona za tuberkulozu na području Firula, jer u Splitu nije bilo dovoljno bolničkih kreveta za sve bolesnike kako bi ih se izoliralo iz obitelji, ali na žalost ta akcija nije uspjela. ${ }^{65}$

62 U Primorskoj banovini umire godišnje 2000 ljudi od tuberkuloze. Novo doba, 14(1931), br. 222, str. 5 (23. IX.). Broj od 2000 smrtnih slučajeva godišnje od tuberkuloze pojavljivao se u liječničkim iskazima u nekoliko navrata. Moguće je da je bio donekle predimenzioniran.

${ }^{63} \mathrm{Rad}$ na suzbijanju tuberkuloze u Splitu. Novo doba, 15(1932), br. 112, str. 6 (14. V.).

${ }^{64}$ Skupština društva za borbu protiv tuberkuloze. Fadranski dnevnik, 2(1935), br. 140, str. 6 (17. VI.)

${ }^{65}$ Akcija protiv tuberkuloze. Fadranski dnevnik, 3(1936), br. 117, str. 7 (20. V.) 
Obavijesti o radu Društva tiskane su i u dalinjem periodu, a gotovo u svakom broju Novoga doba tiskana je poruka:»Upisujte se u Društvo za borbu protiv tuberkuloze«.

\section{Zaključak}

Promicanje zdravstvene edukacije putem novina, časopisa i popularno-znanstvenih publikacija bila je vrlo važna metoda socijalno-zdravstvene prevencije tuberkuloze. Brojna izvješća o radu socijalno medicinske službe, statistički pokazatelji o broju bolesnika od tuberkuloze, opisi teških uvjeta života radnika i uopće siromašnih slojeva u Splitu i splitskom okruženju promovirali su problem oboljelih od tuberkuloze, senzibilizirali javnost za njihove ljudske potrebe i, što je najvažnije, učinili dostupnim barem minimalno znanje o higijeni, zaštiti od bolesti i zdravlju kao kulturnoj kategoriji modernoga doba. Uz to, u javnosti su istaknuti i neki drugi akteri, i njihove potrebe, čija je sudbina do tada bila skrivena ili manje zanimljiva: primjerice potreba zaštite male djece, uloga žene kao majke i čuvarice obiteljskoga zdravlja. Uspostavljajući kontinuitet procesa promicanja zdravstvenoga prosvjećivanja putem različitih medija i stvaranja javnoga znanja, ustvrdili smo da je taj proces u ovom obujmu bio moguć najvećim dijelom zahvaljujući suradnji novinskih redakcija i novinama kao medijima masovne komunikacije.

Postavljajući pitanje kako je došlo do toga da su se masovni mediji komunikacije u tolikoj mjeri uključili u kampanju za suzbijanje tuberkuloze na vrijednostima Štamparove medicinske misli, zaključili smo, ne zaobilazeći aktivan angažman splitskih liječnika koji su prihvatili njegovu socijalno-medicinsku misao, ni rad Društva za suzbijanje tuberkuloze kao građanske udruge, da je to, funkcionalistički gledano, bio odgovor novina na zahtjev okoline da se u Splitu uspostavi odnos između socijalno odvojenih dijelova zajednice i da se tadašnji tiskani mediji, stvarajući pritisak prema središnjoj državnoj vlasti, na odgovarajući način aktivno uključe u rješavanje akutnoga društvenog problema. Novine nisu samo prenosile informacije nego su proizvodnjom članaka o tuberkulozi, na kraju komunikacijskoga lanca, omogućile recepciju dostignutih znanja o sprječavanju zdravstvenih problema, poboljšanju zdravstvenih navika i daljnju reprodukciju informacija o stvarnom socijalnom stanju dijelova društva, razvijajući i snažno suosjećanje prema oboljelima i siromašnima. 


\section{IZVORI}

Fadranski dnevnik, 1934-1938.

Novo doba, 1918-1941.

Pučka prosvjeta, 1921-1932.

\section{LITERATURA}

Baudrillard, Jean: Simulacija i zbilja, Zagreb: Naklada Jesenski i Turk-Hrvatsko sociološko društvo, 2013.

Dugac, Željko: Kako biti čist $i$ zdrav: zdravstveno prosvjećivanje u Hrvatskoj, Zagreb: Srednja Europa, 2010.

Dugac, Željko: »Zdravstveno prosvjećivanje protiv tuberkuloze u međuratnoj Hrvatskoj«. Medicus, 14(2005) 1, str. 155-171.

Hol, Stjuart: Mediji i moć, Beograd: Karpos, 2013.

Ferri, Rafo: Tuberkuloza u Splitu i asanacija grada, Split: Splitska društvena tiskara, 1925.

Grmek, Mirko Dražen: »Životni put Andrije Štampara, borca za unapređenje narodnog zdravlja«. U: U borbi za narodno zdravlje: izabrani članci Andrije Štampara. Zagreb: Škola narodnog zdravlja »Andrija Štampar«: Medicinski fakultet, 1966.

Kraljević, Ljubomir (ur.): Zaslužni splitski liječnici u prošlosti od 1946. do 1975. godine, znanstveni skup, Split 23. rujna 1996. u povodu stodvadesete obljetnice rođenja dr. Jakova Miličića (zbornik radova), Split: Hrvatski liječnički zbor, Podružnica, 1999.

Kuić, Ivanka: »Novo doba - najvažniji splitski i dalmatinski list između dva rata«. Kulturna baština, 39(2013), str. 113-138.

Marasović Šušnjara, Ivana i dr.: »Doktor Josip Škarić (1887-1975). - pionirski pothvati na polju javnog zdravstva na području Dalmacije u prvoj polovici 20. stoljeća«. Acta Med. Croatica, 71(2017), str. 319-326.

Marijan Jelaska, Zdravka: Grad i ljudi: Split 1918.-1941., Zagreb: Hrvatski institut za povijest, 2009.

Propisi za suzbijanje tuberkuloze: otpis C.K. Ministra predsjednika kao upravljača ministarstava unutrašnjih posala, dneva 14. jula 1902. br. 29949. Zadar 1902.

Štampar, Andrija: Pouke o zdravlju, Zagreb: Društvo hrvatskih sveučilišnih građana za pouke analfabeta, 1910.

Štampar, Andrija: »Socijalna medicina«. U: Mirko Dražen Grmek (prir.), U borbi za narodno zdravlje: izabrani članci Andrije Štampara. Zagreb: Škola narodnog zdravlja »Andrija Štampar«-Medicinski fakultet, 1966.

Štampar, Andrija: »O zdravstvenoj politici«. U: Mirko Dražen Grmek (prir.), U borbi za narodno zdravlje: izabrani članci Andrije Štampara, Zagreb: Škola narodnog zdravlja »Andrija Štampar«-Medicinski fakultet, 1966.

Štampar, Andrija: »O socijalnoj terapiji«. U: Mirko Dražen Grmek (prir.), U borbi za narodno zdravlje: izabrani članci Andrije Štampara, Zagreb: Škola narodnog zdravlja »Andrija Štampar«-Medicinski fakultet, 1966.

Štampar, Andrija: »O socijalnoj medicini«. U: Mirko Dražen Grmek (prir.), U borbi za narodno zdravlje: izabrani članci Andrije Štampara, Zagreb: Škola narodnog zdravlja »Andrija Štampar«-Medicinski fakultet, 1966.

Štampar, Andrija: »Pet godina socijalno-medicinskog rada u Kraljevini SHS «. U: Mirko Dražen Grmek (prir.), U borbi za narodno zdravlje: izabrani članci Andrije Štampara, Zagreb: Škola narodnog zdravlja »Andrija Štampar«-Medicinski fakultet, 1966. 


\title{
PUBLIC KNOWLEDGE ABOUT TUBERCULOSIS AND THE ACTIVITIES OF THE SOCIETY FOR THE ERADICATION OF TUBERCULOSIS IN SPLIT (1918-1941)
}

\author{
Ivanka Kuić \\ University library in Split \\ kuicivanka@gmail.com
}

\begin{abstract}
Tuberculosis was a major health problem in Split between the two world wars. Scientific publications, journals, and local newspapers played an important role in health education as one of the preventive treatment methods of this nefarious disease, which is based on Štampar's sociomedical ideas, as well as in shattering prejudices and raising popular awareness of how to face the consequences of the disease. This paper establishes the existence of a continuity in the creation of recorded public knowledge relevant to this topic, with particular reference to the role of mass media such as Novo doba and fadranski dnevnik. Novo doba was a very important political-informative weekly newspaper published from 1918 until 22 April 1941. Fadranski dnevnik was published from 1934 to 1938. Both papers successfully performed their social function of providing information, shaping public opinion, and spreading knowledge, transferring all the complexity and necessity of modernisation practices that were changing Split and making it into a modern city. Among these modernisation practices was the struggle against tuberculosis as a serious socio-medical problem.
\end{abstract}

Keywords: Andrija Štampar; tuberculosis; socio-medical methods; Split 1918-1940; Novo doba; Jadranski dnevnik 